International Journal of Multidisciplinary Studies and Innovative Research

Publisher: Catholic University College of Ghana

ISSN: 2737-7172 (O), ISSN: 2737-7180 (P)

DOI: $10.53075 /$ ljmsirq7547567652

DOI Url: http://doi.org/10.53075/ljmsirq7547567652

\title{
THE SPIRITUAL THROUGH THE BODY AND BEAUTY: ADI SHANKARA'S BHAKTI IN SAUNDARYA LAHARI
}

\author{
Keshav Raj Chalise, PhD \\ Nepal Sanskrit University, Nepal \\ chalisekeshavraj73@gmail.com \\ Copyrights
}

Copyright for this article is retained by the author, with first publication rights granted to the journal. This is an open-access article distributed under the terms and conditions of the Creative Commons Attribution license (http://creativecommons.org/licenses/by/4.0/)

Abstract: Unlike the philosophy of advaita Vedanta focusing on the absolute with nirguna and nirakara, Adi Shankara has practiced the reverence of Devi Parvati as Adi Shakti in Saundarya Lahari with worldly attributes of body and beauty. The verses of Saundarya Lahari depict the image of Shakti as powerful, the most beautiful and the most attractive Devi in worldly form. With the question whether Shankara has intentionally generated a contrast on his philosophy of the absolute or he has seen the absolute in the physical, as the problem in religious philosophy and religious practice, this study examines how Shankara has adored the body and the beauty of Adi Shakti as the means to search the spiritual in body, beauty and attraction.

Keywords: Bhakti, Nirguna, Shakti, the body, the spiritual, the absolute

\section{Introduction:}

\section{Saundarya Lahari and Bhakti}

Myths on Saundarya Lahari say that Adi Shankara went to Kailash intending to venerate Shiva and Parvati when Lord Shiva gave him a manuscript of 100 verses with the description of the many facets of the Goddess. While returning, Nandi grabbed the manuscript from him; tore it into two; took one part and gave him the other one. Feeling disappointed, he ran to Shiva and told the incident. Shiva, smiling, charged him to hold the 41 verses with him as the initial part of the 100 verses and then, write rest 59 verses in praise of the Goddess. As the blessing of Shiva, he wrote them. Thus, verses 1 - 41 are the original work of Lord Shiva, which describe the mystical experience of the union of Shiva and Shakti. Adi Shankara composed the remaining verses (42-100) himself. This part mainly focuses on the appearance of the Goddess. All the 100 verses are collectively known as 'Soundarya Lahari'.

Another story says that once Adi Shankara went to visit Lord Shiva in Kailash. He found Lord Shiva writing about the beauty of Goddess Parvati on the walls of their home. Shiva rubbed what he wrote, as he didn't want Adi Shankara to know about it. But, Adi Shankara, as he was the man with a brilliant mind, saw some part of the writings and with his superior mind recollected the rest. Thus, he composed the Soundarya Lahari (waves of the beauty of the Devi).

Divided into two parts, the first part (verse 1-41) named as "Ananda Lahari" (the waves of happiness) and the second part (Verse 42-100) is named as "Saundarya Lahari" (waves of beauty). With reference to these legends, the book shows his power of creation equal to divine or equal to Lord Shiva. As per the name, the first part describes the mode of pleasure expression and the second part primarily concerns the beauty mode of Devi Parvati. Saundarya Lahari, in this sense, shows Adi Shankara's bhakti to the essence of power, the cosmic principles, Shiva and Shakti and their interrelation. Most of the verses establish the supremacy of the goddess as Shakti. This study explores how these verses highlight the beauty, both physical and spiritual, and how they establish the power of Goddess Parvati as the source of creation with the most beautiful symbol of womanhood and her attributes. 


\section{International Journal of Multidisciplinary Studies and Innovative Research \\ Publisher: Catholic University College of Ghana \\ ISSN: 2737-7172 (O), ISSN: 2737-7180 (P) \\ DOI: $10.53075 /$ ljmsirq7547567652 \\ DOI Url: http://doi.org/10.53075/ljmsirq7547567652}

Studies on Adi Shankara have identified his philosophy of Advait Vedanta in detail, but very little is done in his text, Saundarya Lahari. The point of departure for this research is that this study intends to explore Adi Shankara's quest of the spiritual through his veneration to the beauty and body of Devi Shakti. This research addresses the basic research questions:

a. How has Adi Shankara imagined the body symbols of Devi Parvati?

b. What particular aspect of physical beauty has Adi Shankara praised for Bhakti?

c. How has the poet connected 'the physical' with 'the spiritual' for the quest of the Absolute?

\section{Body: The Way to the Spiritual}

Generally, beliefs and practices in religion strengthen to each other, but Hindu belief and Hindu practices seem to have disparity. Hindu religious belief centers to the spiritual dimension where as majority of religious practices focus on the physical dimension. It is the inimitability of Hinduism. Hindu philosophy, mainly Vedanta talks about the nirguna aspect of the divine power, but Hindu practice keeps idolatry notion at the center in which physical images and symbols of gods and goddesses are worshipped. At its core level, idolatry practice tries to unite the bodily with the spiritual. Worshipping the physical image of the gods/goddesses is the product of the love to physicality. This love to gods and goddesses designates believers' devotion to them, "love considerably facilitates things because the person lovingly devoted to God is automatically above questions of 'meaning'. Everything he does he does for the sake of Him, the Lord (or for the sake of Her, the Divine Mother)" (Torwesten 102). Hinduism, as both religion and philosophy, unites both physical and the spiritual in logical and meaningful way. The physical signifies to the 'body' and the spiritual refers to something beyond the body or material, or the soul.

Similar to Hindu practice, even from Vedic nature idols, Shankara has stressed with the beauty and body of Shakti in Saundarya Lahari though his philosophy of advaita Vedanta has "forcefully stressed that Nirguna Brahman is absolute and without attributes" (Torwesten 119). It has a sense. He has produced the philosophy of nirguna absolute and also, he has praised the body and the beauty of Shakti. Nirguna literally means 'without gunas', that is without the qualities found in prakriti or nature, but he has seen the qualities of beauty and perfection in Shakti that is higher than the ones found in natural world as Shankara has seen Shakti as prosperous mother, "saubhagya janani" (SL 5), "prosperity implies beauty of form, fine accomplishments, progeny, opulence" (Sastri and Ayyangar 37). This prosperity is worldly. Saguna (with worldly attributes) and nirguna (without worldly attributes) are inseparably linked in Shakti. Without the feeling of saguna, nirguna cannot be felt in the way day would have no importance or even the existence if there were no night. Observation and search of beauty image of Shakti in Saundarya Lahari is the love to saguna or maya to the worldly, "maya came to be inseparably linked in people's minds" (Torwesten 122), and maya is saguna, with attributes. Maya is to and about saguna that is physical or bodily. Maya leads to the mode of bhakti, and bhakti leads to the mode of the sense of spiritual. Negatively conceived, maya is what blinds man, and positively perceived, it is the way to go beyond maya itself because "constant mental and physical activity conceals the underlying pure consciousness" (Torwesten 122) of maya. Love to the physical body with the consciousness of devotion to the gods/goddesses, if the physical is supposed as the means to search the essence, properly combines the body and the spiritual.

Shankara has seen the world charged with the grandeur of Shakti, "there is a correct way of seeing the world, namely as being charged with the grandeur of God" (Cottingham 87), and he sees one world, just the world of Shakti, not another world. The world is finite, and the power of the God is infinite. The finite world of body is the manifestation of the infinite one; "God is therefore knowable at least insofar as he is the world-cause. Upon further consideration, additional attributes can also be included in the definition of a God capable of making the world: power, knowledge, will, agency, and so on" (Clooney 40). The body, if charged with the blessings of Shakti, he feels, 


\section{International Journal of Multidisciplinary Studies and Innovative Research \\ Publisher: Catholic University College of Ghana \\ ISSN: 2737-7172 (0), ISSN: 2737-7180 (P) \\ DOI: $10.53075 /$ ljmsirq7547567652 \\ DOI Url: http://doi.org/10.53075/ljmsirq7547567652}

can be merged with the transcendent existence, consciousness and bliss, "blssed are the few that adore thee" (Sastri and Ayyangar 45)i. And, the blessed are only those who have the love and devotion to Shakti.

As Shankara has deep adoration to the goddess (Devi) as Shakti, Hinduism emphasizes on the worship (puja) of images or symbols of one gods and goddesses, worshipping "is also supposed to stress devotion, or bhakti as the means of emancipation from transmigration; and final union with one of the gods" (Inden 109), and his devotional mentality has attributed to the mode of transmigration of the body to the spiritual. Worshipping of the personal gods/goddesses means imagination of the origins upon earth in human form is "the expression of the very natural interest felt by man in his own preservation and the working of the physical forces" (Inden 109). Shankara's image of sakti is embodied power of creation "the gift of poesy, as the result of exclusive worship of the Devi" (Sastri and Ayyangar 83) ii; "she becomes identified with the creative force of the cosmos and the underlying potency of things" (Kinsley 35). Her has the power to generate creativity in humans. It is the power of her body, beauty and the transcendence.

Although "western philosophical and theological schools generally have explained the human body as inferior in contradistinction to the superior soul, spirit, or mind (Knaster 48), Shankara has seen the body as equal to the spiritual. Search of the beauty in the body form in Shakti reflect the notion of search of human aspects in the gods and goddesses, "Shiva and Parvati (Shakti) marry and have children; when humans marry and have children they do so in the context of the mirror- image of the divine world" (Smith 151). They have the image of humans in the way other humans have the body and beauty. This bodily existence of the God/goddess is the real transcending of the body into the spiritual because "the body is the expression of the inner self, that 'the state of the body ... provides an index of the state of the soul ... [for] a whole and perfect body is both a sign of one's moral state" (Smith 151). The perfect body image of Shakti with beauty and attraction in Saundarya Lahari is therefore is the index of the state of the soul or the spiritual. Her body reflects the time domain of all time zone, seasons, nature and nonnature, life and non-life, matter and the beyond matter, and ultimately unites both the physical and the spiritual together because, "spirit that needs the body" (Praagh 2). So, Shankara has applied the bhakti of the physical body of Shakti with perfect image as the quest of the spiritual through beauty as the way "to ground the bhakti religious experience in a thoughtful, conscious approach" (Prentiss 20). Like that of Buddha existing in the worldly form and using the body as the means to quest for the absolute in niraguna, Shankara has generated the body image of Shakti as the means to search the spiritual in the body through bhakti.

\section{Shakti: The Power of Charisma}

Devi, the symbol of power of creation, has equal power of attraction not necessarily of bodily desire. Even she has the supreme power over Shiva and the beauty of the attraction. This attraction has to do with the opposite attraction.

You, who grant all the good things to those who bow at your feet, was worshipped by the Lord Vishnu, who took the pretty lovable feminine form and could move the mind of he who burnt the cities and make him fall in love with him. And the God of love, Manmatha, took the form which, is like nectar, drunk by the eyes by Rathi his wife, after venerating you, was able to create passion, even in the mind of Sages the great. (SL 5. trans. Ramachander 3) ${ }^{\text {iii }}$

With the law of attraction, Shiva is the static power as conscious and Shakti is dynamic power with physics, it is nature or Prakriti, hence essentially beautiful and attractive. She symbolizes for the nature that consists of both good and bad and these elements are attached, attraction bonding (direct) or distraction bonding (indirect). She has the power to create the universe, both good and bad. She is the one who attracts others. She can grant all the good things 


\section{International Journal of Multidisciplinary Studies and Innovative Research \\ Publisher: Catholic University College of Ghana \\ ISSN: 2737-7172 (0), ISSN: 2737-7180 (P) \\ DOI: $10.53075 /$ ljmsirq7547567652 \\ DOI Url: http://doi.org/10.53075/ljmsirq7547567652}

to one who worships her. Referred to the myth of Lord Vishnu getting the power to change the gender after worshipping Devi, Devi possesses the power to transfer one gender to another for the good. Lord Vishnu, changed into a beautiful lady, as the myth tells, has attracted Lord Shiva. Hence, she is the source of attraction to the opposite sex. This opposite attraction has can be seen as the physically attracted to each other, but this attraction has to do with the world and creation as the opposite existence.

Devi (Shakti) united with Shiva, exposes the unitary part of the universe and creation. She is the epitome of Rati, love, and desire and she has the power of attraction to others. Her attraction, throughout the verse as the poet describes, is Shiva-centric resulting in the power of essence, even more, powerful than Lord Vishnu to transfer him into the feminine.

\section{Bhakti to Beauty}

Is beauty only physical or the way to the spiritual? Beauty is merely physical in earthly perception. No doubt, beauty is seen in physics, in the matter, in the body or sense perception. But the physics can be the means to the way to the spiritual. It has a role in the inner level of knowledge, spirituality, and Bhakti to the divine. Bhakti, a Sanskrit originated term especially in Hinduism, denotes the mode of praise, worship or admiration. In its literal sense, it is the expression of attachment, participation, fondness for, homage, faith, love, devotion, worship, and purity. As a remarkable feature and tendency of human existence having to do with one's devoted involvement with a person, object, deity or a creative project. Bhakti through singing God's/Goddesses' name, hear his/her name, write his/her name, draw his/her picture, talk about him/her, live with people who talk about God and Goddess.

Connected with the root word, 'bhaj' with bhakti, is especially reserved for the most superior deities and concentration on God. When the mind is attached to a man or woman, it is passion. When it is attached to money, it is greed. But when the mind is attached to God, it is bhakti. Bhakti causes a transformation in a person's thoughts, actions, and mind, as well as in their reactions, responses, and lifestyle. It regards emotion as the central medium of controlling mind for meditation, as the object of meditation may be anything. A single object can be meditated upon either through jnyana (knowledge) or bhakti or karma or yoga. It is the method of meditation that determines the particular label or name that is given to the mode of bhakti.

Bhakti is a real, genuine search after the Lord, a search beginning, continuing, and ending in love. One single moment of the madness of extreme love to God brings eternal freedom. On such condition, Bhakti is intense love to God and when one gets it, he/she loves all, hates none; he/she becomes satisfied forever. This love cannot be reduced to any earthly benefit because so long as worldly desires last, that kind of love does not come; it is greater than Karma, greater than Yoga because these are intended for an object in view, while Bhakti is a means to get the love and an end to be loved. The Bhakti to the spiritual or to the divine generally ignores the physical beauty in traditional practice, but physical beauty can be a mode of the search of spiritual or Bhakti. Adi Shankara has practiced it and seen beauty in Devi (Shakti) that leads to the mode of Bhakti for a spiritual quest, the quest of knowledge, perfection and divine:

With disheveled hair, with upper cloths slipping from their busts, with the lock of the golden belt getting open due to the haste, and with saris slipping away from their shoulders, hundreds of young lasses, run after the men, who get your sidelong glance, even though they are very old, bad looking and not interested in love sports. (SL 13. trans. Ramachander 6)iv

With Sringaric image, the verse presents the idea that seeing Devi (Shakti) makes an old man regain his virile power, which makes many young women follow him. Even those women do not notice where they are going and how their clothes are falling off their bodies. This means that the old man regains his youthfulness. This erotic can be observed 


\section{International Journal of Multidisciplinary Studies and Innovative Research \\ Publisher: Catholic University College of Ghana \\ ISSN: 2737-7172 (O), ISSN: 2737-7180 (P) \\ DOI: $10.53075 /$ ljmsirq7547567652 \\ DOI Url: http://doi.org/10.53075/ljmsirq7547567652}

as the great sense of Shakti through Bhakti. This reference appears to be erotic at surface level and the expression with spiritual quest in its deep level.

The old man on whom her side-glance had fallen attains elevated mental state, beyond the materialistic world. He gets transformed into a yogi by spiritual enlightenment that happened due to her glance. The women who are described here are animals in essence, ignorant individual souls. Going after an enlightened soul, the old man through the meditation to Devi, to learn and practice the spiritual path with a desire to attain liberation. These women are in urgency and eagerness to know her through him, and they forget everything about the material world, their clothes or robes. This also conveys that when an aspirant is ready for liberation, she sends a spiritual Guru on her own to teach the aspirant during his final journey towards liberation.

At its apparent level, the message of this verse has the erotic impression that the old and weak men get manly power with just a glance of Devi and her beauty and women follow those old men without having a consciousness of falling off their clothes. But at its deeper level, it has the sense that the old men are the gurus who have been enlightened by the glance of Devi and the women as earthly beings follow them to get the knowledge and enlightened. Hence, liberation or mental freedom becomes possible through knowledge, the state of being away from ignorance, but this becomes possible through beauty and love. The old men have got enlightenment through the sight of Devi and women follow the man as the guru to be enlightened. The love transfers into Bhakti.

\section{Bhakti and Body Symbols}

Beauty or ugliness is a perception. The thing itself is neither beautiful nor ugly; rather it is the perception it makes so. The perception has to do with the symbols and emblematic association, "Nothing is meaningless or neutral: everything is significant. Nothing is independent, everything is in some way related to something else" (Cirlot xxx). The relation and representation of one thing to another idea or abstract form is a symbolized meaning. These meanings are the results of human perceptions. The things are the objects, and their meanings are the results of perception, and so do happen in the perception of the images of gods and goddesses. Similarly, the body parts of Devi show the beauty at the symbolic point and these body parts inherently present her beauty and poet's devotion, praise and Bhakti at the wider insight. The poet presents the hair of Devi as the symbol of beauty and love:

O! Consort of Śiva! Your dark, thick, naturally fragrant, soft, lustrous hair appears like a forest of fully blossomed blue colored lotus flowers, removes our darkness of ignorance. I presume that divine flowers in Indra's garden live in your hair to get their fragrance. (SL 43. trans. Ramachander 19)v

Devi, known as Parashakti, has her hair as a thick forest, full of entirely blossomed blue colour lotus flowers. Divine flowers reared in Indra's garden take a break in her hair to derive their fragrance. The blue-colored flowerlike hair becomes the source to remove the darkness or the ignorance of human beings.

Is this the fragrance of the flower on her hair or the fragrance of her hair on the garden flowers? Such a beauty and natural fragrance she has ever got that is the source of life and intelligence. Flowers in Indra's garden are the most fragrant of all the flowers. Even these flowers derive their fragrance only from her hair. Her hair is lustrous blue or shining in colour. The verse praises her hair, the beauty and erotic image with the movement from physical to trans-physical as this beauty removes the ignorance away towards spiritual perfection, as "in Hindu symbolism, hairs, like the threads of a fabric, symbolize the 'lines of force' of the universe" (Cirlot 135). It is not only beautiful but also powerful that drives the ignorance away. It shows that her physical beauty is the source of knowledge and wisdom, a way to the mode of spiritual perfection.

Seeing the image of Devi (Shakti) makes a man physically virile and feels illuminated. Her beauty gives man physical strength and praising her and meditating to her brings one even the power of spirituality and knowledge. Combined with both physical and spiritual, the poem further poses her praise (bhakti) through her beauty: 


\section{International Journal of Multidisciplinary Studies and Innovative Research \\ Publisher: Catholic University College of Ghana \\ ISSN: 2737-7172 (0), ISSN: 2737-7180 (P) \\ DOI: $10.53075 /$ ljmsirq7547567652 \\ DOI Url: http://doi.org/10.53075/ljmsirq7547567652}

He who meditates on the luster of your beautiful body, which is blessed by the rising sun, and which dissolves the sky and the world, in light purple hue, makes celestial damsels like Uravasi and others, who have eyes like the wild startled deer, follow him like slaves. (SL 18. trans. Ramachander 9) vi

What a beauty, gleam and tenderness Devi has as such she has the power to transfer others to be very attractive. Her beauty and attraction are one, and her power transfers the males with a youthful hue. One, who meditates on her form as deep red, attains immense energy and he/she attracts everyone in the world with an indirect praise of Devi and her impression. At its surface level, it highlights her physical influence and spiritual supremacy. Even only the meditation on her with shining red complexion gives the meditator youthful and attractive form that is capable of influencing everyone's mind towards him. These meditators are Gurus.

Her redness, the symbol of beauty, power, and sexuality, refers to her compassion. This colour makes man, the meditator powerful in such a way to attract the beauties of the world. This red color resembles the Teja (glow of light) as beautiful as celestial beauties like Urvasi. The celestial damsels; though are attracted towards him, her Bhakta, experience inner fear of going anywhere near him which is expressed through their fearful eyes. Their fearful eyes equate to the appalling eyes of young deer in the forest. Such fear is reflected in the eyes of these celestial damsels. Though they are passionate, they are scared of going anywhere near him. On one side, they are passionate and on the other side they express fear, both are reflected through their eyes in the way ignorant people feel fearful in front of the erudite one, and as a result of which, their eyes appear like the eyes of young deer in the forest. Their passion resembles to the passion of knowledge and Bhakti.

Beauty cannot merely be understood as the physical or material beauty; it is the essence of nature and creation. Devi resembles the beauty of nature at her physical level and also resembles spiritual beauty and creation of the universe through the bindu and triangle:

Hey, Mother who is Goddess of all universe, he who meditates on you, as the crescent of love of our lord great, on the dot of the holy wheel, your two busts just below, and you as the half of Shiva our lord, not only creates waves of emotion in ladies, but charms the world, which has moon and sun as busts. (SL 19. trans. Ramachander 9) vii

The two parallel dots are her bosoms by which this universe is nurtured and a single dot above these two dots is her third eye. The bosoms have a sense of erotic expression of beauty and sexuality with her identity of Kameshori, kama as the physical desire attached to Shiva, Kameshor. Her erotic is not to any other but kameshor, Shiva. At its surface level, the love and kama represent physicality, but to its deeper level, it reflects the greater mode of worldly creation; will the creation continue if the physical desire is completely ignored? The three dots (bindus) represent sun, moon, and fire. Bindu is called the highest light. The highest form of light naturally should be the origin of light from which all others should have emerged.

Two triangles, upper and lower or one above the other, her face and her two bosoms form the upper triangle; the connection of body and mind, and her organ of manifesting the universe form the lower triangle. Her face is the bindu, and below the face are her two bosoms and below the bosoms is the Yoni, the source of creation, from where the universe begins.

With the image of bindu, one should meditate on her face, bindu and her two bosoms below her face. When an aspirant can meditate on this subtler form of the Divine image, she becomes highly energetic like damsels in all the three worlds, including celestial damsels. The celestial damsels have sun and moon as their bosoms. Despite having the sun and the moon as their bosoms, they are still attracted to the one who meditates on her kamakala form that is Shiva. Her bosoms represent for the sun and the moon. An ignorant person sees bosoms just as bosoms, but a real Bhakta sees the sun and the moon in them, one sees sexuality and the other sees the power of creation as her 


\section{International Journal of Multidisciplinary Studies and Innovative Research \\ Publisher: Catholic University College of Ghana \\ ISSN: 2737-7172 (O), ISSN: 2737-7180 (P) \\ DOI: $10.53075 /$ ljmsirq7547567652 \\ DOI Url: http://doi.org/10.53075/ljmsirq7547567652}

beauty has the attachment with the sun and moon, "the sun is the source of light and that light is symbolic of the intelligence and the spirit, then the process of seeing represents a spiritual act and symbolizes understanding" (Cirlot 99). Her beauty, therefore, has a symbolic association with spirituality.

This mode of physical combination of the triangles and bindus as the combination of erotic kama and spiritual creation goes on continuous description through the same mode of beauty perception:

By nature, slightly curled, and shining like the young honey bees your golden thread like hairs, surround your golden face. Your face makes fun of the beauty of the lotus. And adorned with a slightly parted smile, showing the tiers of your teeth, which are like the white tendrils, and which are sweetly scented. Bewitches the eyes of God, who burnt the god of love. (SL 45. trans. Ramachander 20) ${ }^{\text {viii }}$

Her thick and parting hair embodies the images of beauty and the origin of beauty in nature. The center of the parted portion acts for an overflowing stream, with the waves of the beauty, the origin of the Saundarya Lahari in the world. This parting incorporates two domains: good and bad, beauty and ugly, dark and light, Sringra and Bhakti, the physical and the spiritual, abstract and concrete and so many other oppositely existing forms. As this parting represents for the wave of beauty, the combined existence of opposite values is the beauty of the world. When the hair is parted on the top of the head, the white colour of the skull becomes visible and this parting appears like a stream overflowing with floodwater, the wave of beauty, Saundarya Lahari. Lahari means waves and waves appear only on the shore and not in the center of the ocean. The beauty begins from center and passes through her hair and its parting and moves to the side, in which the central beauty is the beauty of the spirituality and the seen beauty is like the waves, partings and the hair in the form of the world and the life, the physical. The beauty of her face that is visible is only an insignificant thing compared to her inner beauty that is her spiritual or the Shakti. The ignorant one or a common individual sees her beauty of the hair, and only the Bhakta can see the inner beauty beyond her physical and is beyond normal human comprehension.

Symbolically, hair symbolizes beauty and Sringar, the erotic, and the spiritual at a time. The colour of the hair makes meaning differently. Darkness of the hair is maya (love) or ignorance. Devi has got golden hair, and "hairs, then, come to symbolize the concept of spiritualized energy" (Cirlot 135) not the dark one. Maya, as inherence to everyone, is a driving force to ignorance, and since she has the golden hair, one who has Bhakti to her is easily capable to be released from ignorance. Ignorance leads to the love to sansar or mundane existence, but Bhakti to Devi or Shakti with golden hair helps one to get rid of sansar. Seeing the beauty of the golden hair and it's parting just as beauty is Sringaric view to her, but Bhakti to her is the way to be free from mundane reality and materiality. Her golden hair and golden face appear more beautiful than the lotus flower and the eyes even capable of burning the god of the love. Her eyes with beautiful appearance do not have the essence of physicality; they have the power to burn the lust, and to favour the Bhakti to her as the source of the spiritual quest.

Oh, flower bud, who is the headgear of the king of mountains, wearing black eyebrows above, resembling the feathers of eagle, and determined to destroy peace, from the mind of he who destroyed the three cities, your two eyes elongated up to thine ears, enact the arrows of the God of love. (SL 52. trans. Ramachander 23) ${ }^{\mathrm{ix}}$

As the daughter of Himalaya, Parvati (Devi) has extreme natural beauty, especially her eyes- eyes extend up to the ears and eyelashes look like feathers of a bird, these eyes disturb the tranquility of Shiva, as they appear extended up to the ears like a shining arrow of Manmatha.

Her shiny eyes extended up to the ears have the common reference to physical beauty and also her third eye becomes most active in which "the possession of two eyes conveys physical normality and its spiritual equivalent, and it follows that the third eye is symbolic of the superhuman or the divine" (Cirlot 100). Her eyelashes analogous 


\section{International Journal of Multidisciplinary Studies and Innovative Research \\ Publisher: Catholic University College of Ghana \\ ISSN: 2737-7172 (O), ISSN: 2737-7180 (P) \\ DOI: $10.53075 /$ ljmsirq7547567652 \\ DOI Url: http://doi.org/10.53075/ljmsirq7547567652}

to feathers of a bird, eagle is so soft and have the power to distract the mind of Shiva. She does have beautiful eyes and they are capable enough to destroy the peace in Shiva, but these eyes do not denote sexuality because Shiva has not looked into her eyes nor she has looked at him this moment. It means eyes are beautiful on their corporeal form but they are not for the physical attraction to cause any distraction in the mind of Shiva in erotic sense; rather it is the distraction on peace and tranquility within. Her eyes possess the inner beauty to look into the spiritual but not the physical. One who has the sense of physicality finds the eyes as sensual, but a real Bhakta finds the path to move into the spiritual through her beautiful eyes.

Oh goddess, who is the daughter of the king of mountains, who will not but believe, that the two arched ridges between your eyes and ears are the flower bow of the God of Love? Side glances of your eyes piercing through these spaces make one wonder as if the arrows have been sent through thine ears. (SL 58. trans. Ramachander 23) $\mathrm{x}$

The beauty of Devi with curved space between her eyes and ears has analogous meaning to the beauty of kamadeva. The way she sees through the outer corner of her eyes produces radiant beauty of concentration and appears like fixing an arrow of flower to the bow. With reference to her keenness and concentration with curved appearance, one may see the erotic physics of Devi, but this Sringara has the connection with the myth of Shiva and Shakti finely conveying to a creative aspect of the divine. Just seeing into her fixing eyes appears as if she has sent the arrows through her eyes, and the arrow appears to be the arrow of love, the physical one arousing the sense of the erotic to ignorant ones, but this arrow is the arrow of knowledge, understanding and the spirituality to the ones who have real Bhakti to her like Shiva.

\section{Conclusion: The Absolute in Beauty}

The relation between Sringar and Bhakti equals to the relation between the physical and the spiritual or the relation between the body and the absolute. Adi Shankara has united these two domains in Saundarya Lahari. The poet, as a Vedantist, views holistically and integrates aspects of body and the absolute in Parvati as adi-Shakti, and also, he, as a Shaiva Vedantist, feels the sense of the essential cause in Shiva Shakti. Saundarya Lahari approves his belief on the absolute as the combination of material body, Prakriti in the beauty of Parvati with the depiction of Sringaric appearance in form and the beauty of essence as the absolute in the united form of Shiva and Shakti together in the mode of ultimate creation.

Religious traditions generally do not recognize body and bodily activities as a gateway to mystical experience or encounter with the divine. They provide the lessons that the physical world and the sensuality to look into the material world is the hindrance to the journey to the knowledge of the spiritual. Moving above the traditional religious practices, Adi Shankara has provided a major insight to see the essence of the spirituality through the physical, however he has never been in favour of the physical in any of his other writings.

As a devotee and the one who has established Shaktipeethas in different locations of India, at the time of extreme Buddhist impact over Hindu communities, he would not have been able to reestablish Hindu doctrines talking sterile ideas of Brahma and the Absolute among them. Also, Buddhism had focused on the pure spirituality and the purification of the soul. Adi Shankara has given no place to the physical beauty and the domination of sense perception in his Vedantic lessons, but he has shown the concept of the importance of the physical to achieve the spiritual that is the absolute in Saundarya Lahari.

\section{Reference}

Adi Sankara. Saundarya Lahari. Translated by P. R. Ramachander. Banglore, ND.

Adi Sankara. Saundarya Lahari. Translated and edited by S. Subrahmanya Sastri, and Srinivas Ayyangar, 


\section{International Journal of Multidisciplinary Studies and Innovative Research \\ Publisher: Catholic University College of Ghana \\ ISSN: 2737-7172 (0), ISSN: 2737-7180 (P) \\ DOI: $10.53075 /$ ljmsirq7547567652 \\ DOI Url: http://doi.org/10.53075/ljmsirq7547567652}

Theosophical Publishing, 1948.

Cirlot, J. E. A Dictionary of Symbols. Routledge, 1971.

Clooney, Francis X. Hindu God, Christian God. Oxford UP, 2001.

Cottingham, John. The Spiritual Dimensions: Religion, Philosophy and Human Value. Cambridge UP, 2005.

Inden, Ronald. Imagining India. Indiana UP, 2000.

Kinsley, David R. Hindu Goddesses: Visions of the Divine Feminine in the Hindu Religious Traditions. University of California Press, 1988.

Knaster, Mirka. "Body". Encyclopedia of Religion and Spiritual Development. SAGE,

Prentiss, Karen Pechilis. The Embodiment of Bhakti. Oxford UP, 1999.

Potter, Karl H. ed. Encyclopedia of Indian Philosophy: Advaita Vedanta up to Samkara and his Pupils. Vol. III. Motilal Banarsidass, 1981.

Praagh, James Van. Adventures of the Soul. Hay House, 2014.

Smith, David. Hinduism and Modernism. Blackwell, 2003.

Torwesten, Hans. Vedanta: Heart of Hinduism. Grove Press, 1985.

${ }^{\mathrm{i}}$ Suravitapivatiparivrite (SL 8)

${ }^{i i}$ kabindram cheta kamalavanabalataparuchim (SL 16)

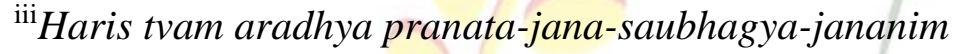

Pura nari bhutva Pura-ripum api ksobham anayat;

Smaro'pi tvam natva rati-nayana-lehyena vapusha

Muninam apyantah prabhavati hi mohaya mahatam. (SL 5)

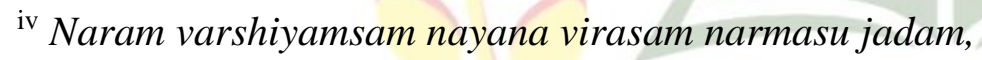

Thava panga loke pathitha manudhavanthi sathasa

Gala dweni bhandha kuch kalasa visthrutha sichaya

Hatath thrudyath kanchyho vigalidha dhukoola yuva thaya. (SL 13)

${ }^{\mathrm{v}}$ Dhunotu dhvaantam nas tulita-dalit'endivara-vanam

Ghana-snigdha-slakshnam chikura-nikurumbham thava sive;

Yadhiyam saurabhyam sahajamupalabdhum sumanaso

Vasanthyasmin manye vala-madhana-vaati-vitapinam. (SL 43)

${ }^{\text {vi }}$ Thanuschayabhi sthe tharuna-tharuni-srisarinibhi

Divam sarva-murvi-marunimani magnam smaranthi ya

Bhavanthasya thrasya-dhwana-harina shaleena nayana

Sahervasya vasya kathikathi na geervana Ganika. (SL 18)

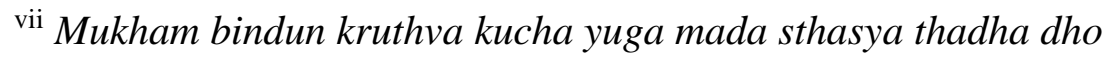

Harardha dhyayedhyo haramamahishi the manmathakalam

Sa sadhya samkshebham nayathi vanitha inyathiladhu

Thrilokimapyasu bramayathi ravindu sthana yugam. (SL 19) 


\section{International Journal of Multidisciplinary Studies and Innovative Research}

Publisher: Catholic University College of Ghana

ISSN: 2737-7172 (0), ISSN: 2737-7180 (P)

DOI: $10.53075 /$ ljmsirq7547567652

DOI Url: http://doi.org/10.53075/ljmsirq7547567652

viii Aralaih swabhavyadalikalabha-sasribhiralakaih

Paritham the vakhtram parihasati pankheruha-ruchim;

Dara-smere yasmin dasana-ruchi-kinjalka-ruchire

Sugandhau madhyanti Smara-dahana-chaksur-madhu-lihah. (SL 45)

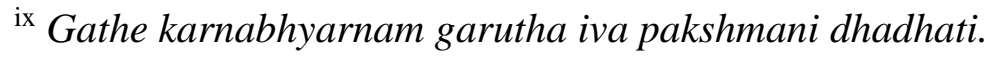

Puraam bhetthus chitta-prasama-rasa-vidhravana-phale;

Ime nethre gothra-dhara-pathi-kulottamsa-kalike

Tav'akarn'akrishta-smara-sara-vilasam kalayathah. (SL52)

${ }^{\mathrm{x}}$ Araalam the paali-yugalam aga-rajanya-thanaye

Na kesham adhatte kusuma-shara-kodhanda kuthukam;

Tiraschino yathra sravana-patham ullanghya vilasann-

Apaanga-vyasango disati sara-sandhana-dhisanam. (SL 58) 